\title{
HISTORY OF THE LINGUISTIC AND CONCEPTUAL PICTURES OF THE WORLD FORMATION
}

\begin{abstract}
Summary. In recent years, there has been an increasing interest in the phenomenon of interaction between two phenomena of human life - language and culture. That is why the problem of exploring the cultural identity of people, which is reflected in the linguistic picture of the world (LWP), is becoming increasingly important. The LWP is closely linked to the conceptual picture of the world (CWP), since the latter exists in the form of concepts that have linguistic expression. The article is devoted to the theoretical foundations of the modern linguistics fundamental concepts, which include the concepts of "linguistic picture of the world" and "conceptual picture of the world". Traditionally, scientists divide the picture of the world into a linguistic picture of the world - an image of the environment, realized by means of language nominations, and a conceptual picture of the world - a system of concepts formed on the basis of human ideas, consisting of concepts. Today the question of the world pictures study remains open, in particular, the development of general theoretical principles such as nomination and definition of basic concepts, their structure continues. The question of structure is solved in different ways (from the maximum convergence of linguistic and conceptual pictures to the recognition of the different degree of originality of the world reflection in each language. The scientists'views on the interaction of these two pictures of the world can be divided into four groups: 1) the linguistic picture of the world and the conceptual picture of the world are not distinguished, because the linguistic picture of the world as a set of human knowledge about the world that functions in language does not exist (G. Kolshansky); 2) the linguistic picture of the world completely covers the content of the conceptual picture of the world, i.e. the linguistic picture of the world makes the picture of the world more accurate (G. Brutyan, J. Sokolovskaya); 3 ) the linguistic picture of the world exists as part of the conceptual picture of the world, which is richer than the linguistic (Yu. Karaulov, O. Kubryakova, B. Serebrennikov); 4) the linguistic picture of the world and the conceptual picture of the world are combined, but do not cover each other (I. Golubovska, T. Kosmeda, L. Lysychenko, S. Ter-Minasova). The problem of classification and the existence of partial pictures in general is also not finally solved, which is considered in the presented study.
\end{abstract}

Keywords: concept,conceptosphere,microconceptosphere, linguistic picture of the world, conceptual picture of the world.

Problem statement. The modern period of development of linguistics is determined by the fact that language is considered not only as a system, but also as a certain picture of the world. According to Yu. Karaulov, "the expression "picture of the world" remains a metaphor, because there are still no explicit procedures for its construction" [5, p. 246], so the concept of the picture of the world is based on "a set of human ideas about its environment" $[11$, p. 1]. The environment is a "man in interaction with the surroundings" [9, p. 8], and the picture of the world is "a consequence of the information processing about the reflection of the real world in the human mind" $[2$, p. 6], i.e. the picture of the world is a synthetic panoramic view of a particular reality, and of each individual place in it.

Analysis of recent research and publications. Representatives of various Ukrainian linguistic schools, in particular I. Golubovska, M. Dmytrenko, S. Zhabotynska, T. Kosmeda, L. Lysychenko, O. Potebnya, J. Sokolovska, made a significant contribution to the development and formation of the concept of the picture of the world. A prominent place in this field belongs to such linguists of the Soviet and post-Soviet period as O. Radchenko, B. Serebrennikov, J. Sternin, S. Ter-Minasova, N. Shvedova. Among the linguists of Western school it is worth mentioning the names of W. Humboldt, M. Birvish, R. Jackendoff, J. Lakoff, R. Pavilionis, A. Farmer, A. Chenki. The works of these scientists are the basis for further researches and form the theoretical base of the study.

Aim of the research on the basis of a comprehensive analysis to clarify the uniqueness of different approaches to understanding the concepts "linguistic picture of the world" and "conceptual picture of the world" in modern linguistics.

Main material presentation. The term "picture of the world" was first use at the turn of the nineteenth and twentieth centuries in the projection on the physical picture of the world (G. Hertz), in the aspect of logic and philosophy it was proposed by L. Wittgenstein, and in anthropology, semiotics, and hence in linguistics, the "picture of the world" came from the works of $L$. Weisgerber.

In linguistics, the concept of the picture of the world and the ways of seeing the world was developed by W. von Humboldt on the doctrine of "inner form" and "spirit of the people". According to $\mathrm{W}$. Humboldt, language is a representation of the national spirit, which he identifies with the national language: "in language we always find an alloy of eternally linguistic nature with what is perceived by language from the nature of the nation" $[4$, p. 373]. Based on this, I. Golubovska notes: "The interpretation of the term "linguistic picture of the world" should be based on the meaning that V. Humboldt invested in the concept of "language form" [3, p. 26-27], and 0. Radchenko believes that the discovery of the phenomenon "the picture of the world" in its various terminological design has become the main theoretical achievement of Humboldt, because without using the term "picture of the world", this linguist describes it almost completely. Similarly, without using the terms linguistic and conceptual picture of the world, W. Humboldt points to the possibility of the existence of these concepts: "The human spirit always seeks to free itself from "the shackles" of language: words constantly connect the inner feeling, which is always fuller than their meaning" [3, p. 103]. 
Influenced by W. Humboldt's philosophy of language, the concept "the picture of the world" was first developed in Slavic linguistics by O. Potebnya, who proceeded from W. Humboldt's understanding of the nature of the word, primarily from what the latter understood by the term "internal form". The word, according to O. Potebnya, consists of three elements: "external form, i.e. articulate sound; sense that is objectified through sound; internal form or the nearest etymological meaning" $[10$, p. 160]. Although the question of the internal form occupies an important place in the general linguistic conception of O. Potebnya, he does not give a single complete definition. First, O. Potebnya defines the internal form as the ratio of representation to meaning. Next, a more complex definition is given: "the inner form is the center of the image, one of its features, which prevails over all others" $[10$, p. 130]. But he is not satisfied with the meaning of this definition. "The internal form," notes O. Potebnya later, "in addition to the actual unity of the image, gives knowledge of this unity; it is not the image of the object, but the image of the image, i.e. the imagination" $[10$, p. 131]. The internal form does not arise by itself - it is created. The process of its creation is connected with the work of thinking, and thinking, according to O. Potebnya, is objectified by words.

Analyzing the scientific heritage of O. Potebnya, L. Lysychenko notes that in his scientific concept "there is a noticeable distinction between mental and linguistic essence of languages, but he considers them in the ratio of subjective (actually mental representations of each individual) and objective - in the form of meanings, which is a collective property" [8, p. 72]. Thus, the scientist was close to the statement and coverage of such concepts as the linguistic picture of the world.

Today, the concept "picture of the world" belongs to those fundamental concepts that have a dual nature. On the one hand, it is a mental formation - the sum of "senses and ideas about the world, which are organized in the human head for one or another reason in an integrated system" [7, p. 141], that is, it is that which comes primarily from man, the fruit of his perception, fantasies, thought processes and transformational activities, a structure that is represented as a reflection of the individual subjectivity. On the other hand, it is an objectified formation that is externalzed by linguistic forms, i.e. "the picture of the world is the secondary existence of the objective world, which was fixed and realized in a peculiar material form. This material form is language, which performs the function of objectification of individual human consciousness as a separate monad of the world" [6, p. 15]. And given that, starting with G. Hertz, M. Planck and A. Einstein, scientists have studied pictures of different "Worlds" (chemical, biological, physical, etc.), then, according to J. Sokolovskaya, it seems logical "Languages World", and therefore, "it is logical to assume the existence of "Linguistic picture of the world" $[11, p .6]$.

Philosophers G. Brutyan, R. Pavilionis, D. Rudenko were the first who started to discuss the problem of the linguistic picture of the world. In linguistics, the study of this issue was unfolded in connection with the thesaurus study of vocabulary and the identification of the compiling ideographic dictionaries principles, which is represented in the works of Yu. Karaulov. At the stage of formation, in parallel with the concept of "linguistic picture of the world" synonyms "linguistic image of the world", "linguistic model of the world", "naive picture of the world", "internal representation", "linguistic organization of the world", "linguistic intermediate world", "mental representation" were used, but lately the term language picture of the world (LWP) is most often utilized, which we use in our work.

The LWP in its most general form can be defined as a set of knowledge about the world, reproduced in vocabulary, phraseology, grammar. Accordingly, the linguistic picture of the world means the image of the whole existing integral and multipart world produced by centuries-old experience of the people and realized by means of linguistic nominations, which represents, firstly, man, his material and spiritual life and, secondly, everything around him: space and time, animate and inanimate nature, the branch of man-made myths and society. Thus, when studying the linguistic picture of the human world, it is possible to consider the recorded and reflected social aspects of life (character, actions, ethics, morality), as well as the experience of self-knowledge of many generations over a long period of time.

The picture of the world is how a person imagines the world in his imagination - "a phenomenon more complex than the linguistic picture of the world, that is, the part of the conceptual world of man related to language, because not everything is perceived and known by man or passes through various senses, has or acquires a verbal form" [7, p. 142]. The picture of the world is how a person imagines the world in his imagination, that is "a phenomenon more complex than the linguistic picture of the world, so, the part of the conceptual world of man related to language, because not everything is perceived and known by man or passes through various senses, has or acquires a verbal form" [7, p. 142]. G. Brutyan noted that "the process of reproducing the picture of the world in the human mind is mostly represented in the form of sensory and rational (logical) model of reality", but "it is also legitimate the depiction of the picture of the world in the form of conceptual (logical) and linguistic models" [1, p. 108]. That is why scientists record the existence of a conceptual picture of the world (CWP), which is also called scientific (Yu. Apresyan, I. Golubovska), conceptual (O. Babayeva), conceptual or cultural (S. Ter-Minasova), logical (Yu. Apresyan, G. Brutyan), cognitive (Z. Popova, J. Sternin). The criterion for distinguishing between linguistic and conceptual pictures of the world is the opposition "thinking - language", in particular, referring to the meaningful interpretation of the concepts of "linguistic" and "conceptual" picture of the world, Yu. Karaulov concludes: "The main elements that make up the first are semantic fields, while the conceptual picture consists of higher levels units, that means groups and superconcepts, which are represented as "constants of consciousness" [5, p. 271].

In the modern scientific literature there are several definitions of CWP. Using the definition of S. Ter-Minasova (CWP is a reflection of the real picture of the world through the prism of concepts formed on the basis of human ideas, obtained through the senses and reflected in his mind, both collective and individual [12, p. 41]), as well as, given the fact that CWP consists of "constants of consciousness" (concepts), we propose the following definition: conceptual picture of the world is a system of concepts formed on the basis of human ideas, obtained through the senses and reflected in his mind, both collective and individual, consisting of concepts images, ideas, concepts, attitudes and evaluations.

Speaking about pictures of the world, L. Lysychenko notes that "one of the important issues related to the essence of the linguistic picture of the world is the question of its structure, which is solved in modern linguistics in different ways (from the maximum convergence of linguistic and conceptual pictures of the world to 
the recognition of different degrees of originality in the reflection of the world in each language)" [8, p. 70]. The question of the pictures' relationship is quite complex, because both pictures of the world are interconnected and are in a state of continuous interaction. The views of scientists on the interaction of pictures of the world can be divided into 4 groups:

1. According to G. Kolshansky, a separate linguistic picture of the world, as a set of human knowledge about the world, functioning in language, does not exist. The term "picture of the world" refers only to thinking, in particular G. Kolshansky writes: "It would be correct to speak not about the linguistic picture of the world, but about the linguistic-mental picture of the world, or conceptual" [6, p. 37], i.e. linguistic and conceptual pictures of the world are not distinguished.

2. Analyzing the features of each of the pictures of the world, G. Brutyan notes that "the main content of the language model of the world completely covers the content of the conceptual model (this part is invariant and does not depend on the specific language)" [1, p. 109-110]. His opinion is supported by J. Sokolovska when she writes that "outside the conceptual model there are peripheral areas, which by their nature are purely linguistic and contain additional information, additional knowledge about the world" [11, p. 104]. Thus, the linguistic picture of the world, according to these researchers, makes the picture of the world more accurate: it complements the conceptual picture.

3. The opposite opinion is held by O. Kubryakova, who argues that the linguistic picture of the world exists as part of the conceptual picture that develops in the process of objective and cognitive human activity [7, p. 143]. Yu. Karaulov also speaks about the incompleteness of the linguistic picture of the world in comparison with the conceptual one: "The linguistic picture of the world is characterized by gaps, "holes due to its fragmentary nature and incomplete system" [5, p. 273].

4. A completely different point of view is defended by S. Ter-Minasova, who writes that "it is more correct to speak not about the relation part - whole, language - part of culture, but about interpenetration, interconnection and interaction on the grounds that language is part of culture, but culture is only part of the language. Thus, the linguistic picture of the world is not completely absorbed by the cultural" [12, p. 47]. I. Golubovska concludes that "interacting and interacting, both pictures exist in parallel dimensions of different types of consciousness" [3, p. 32]. The result of this is the statement of L. Lysychenko, who notes that the pictures "combine, but do not cover each other" [8, p. 70]. However, the mentioned linguists do not deny that CWP is fuller, richer and deeper than the corresponding linguistic picture.

After analyzing the available views and agreeing with O. Kubryakova and B. Serebrennikov that not all units of human mental activity (images, concepts), which have their own internal form of representation (nonverbalized), acquire a linguistic form, we agree with T. Kosmeda, L. Lysychenko and S. Ter-Minasova that the LWP and CWP intersect, but do not completely cover each other.

Along with LWP and CWP, linguists distinguish before linguistic (L. Lysychenko); scientific and artistic (V. Ivashchenko); indirect and indirect(Z.Popova, J. Sternin); national-linguistic(I.Golubovska); universal and ideoethnic (N. Novikova, V. Cheremisina); national, individual and author's (Yu. Vaseiko, T. Masytska); sexual, normal sexual, deviant sexual (O. Kholod). The presence of a large number of pictures of the world, embodying different worldviews of people, is "not a subjective whim of history, but its objective necessity"
[9, p. 31], because the knowledge gained by individuals in the process of life depends on their individual and social experience and allow us to talk about the variability of world pictures. Thus, in the general picture of the world it is possible to allocate partial pictures, each of which differs in language originality. V. Postovalova offers a classification of such partial pictures of the world, which are based on the categorical activity paradigm: 1) the subject of the picture of the world ("who"), the one who depicts; 2) the subject of the picture of the world ("what"), what is depicted; 3) the consequence of activity (actually the image) [9, p. 31-32].

I. The subject of the picture of the world (looks at the world and depicts his vision) depends on the psychological factor that forms a certain picture of the world. In psychology, it is customary to distinguish between individual, collective, ethnic, national consciousness, which correspond to the eponymous pictures of the world.

a) individual (individual-personal) picture of the world reflects reality through the prism of the worldview of the individual. The subject of such a picture becomes an individual;

b) the collective picture of the world is a total amount of common knowledge and ideas of a particular team, the subject of which is a separate group of people (society). This picture can also be divided into partial: professional, territorial, social;

c) the national (ethnic) picture of the world is a worldview of the ethnos expressed by means of a certain language, a verbalized interpretation by the linguistic society of the surrounding world. Entire nations become the subject of such a picture of the world. The existence of a national picture of the world is recognized by most scientists. However, G. Kolshansky categorically denies the possibility of a unique vision of the world by different peoples. The main argument is the position of the common nature of thinking for all people, and the difference in the social experience of peoples is not related to the picture of the world [6];

d) universal picture of the world is the global perception of people of all their relationships and contacts with the world. The subject of the universal picture of the world is humanity as a whole.

II. The subject of the picture of the world. According to V. Postovalova, "in each independent sphere of social consciousness - mythology, religion, philosophy - there are special ways of worldview, their "prisms" through which a person sees the world", and "the result of such a worldview are the corresponding pictures of the world" $[9$, p. 33]. The multiplicity of such pictures of the world is due to the level of intellectual or aesthetic development and education of the individual. The terms local and scientific picture of the world are used in parallel to denote scientific ontologies that contain ideas about the world and are a special form of scientific experience. The scientific picture of the world is divided into a number of interrelated concepts, each of which denotes a separate type of scientific picture of the world as a special level of systematization of knowledge.

III. Consequence of activity (actually the image). The last feature that distinguishes the pictures of the world is "the type of image in the picture, the technique of its execution, characterized by the following features: 1) whether the subjects look at the world with the same eyes; 2) whether the subjects look at the world from one position; 3) whether the same distance from the subjects to the world; 4) whether the world is represented by subjects with the same development of all its parts or with unmotivated accentuation of only some parts" [9, p. 34]. 
Conclusions. Despite the fact that modern scientists address the problems of worldviews, it is difficult to identify positions that would become commonplace. Thus, summarizing the review of approaches to understanding the pictures of the world, we emphasize that the question of their study remains open, in particular, continues the detailed development of general theoretical principles: nominations and definitions of basic concepts, their structure and more. The problem of classification and the existence of partial pictures in general is finally unsolved, which is promising in the modern period.

\section{References:}

1. Брутян Г. Язык и картина мира. Философские науки. 1973. № 1. С. 108-111.

2. Вежбицкая А. Прототипы и инварианты. Язык. Культура. Познание / пер. с англ.; отв. ред. М.А. Кронгауз. Москва : Русские словари, 1996. С. 201-230.

3. Голубовська I.О. Етнічні особливості мовних картин світу : монографія. Київ : Логос, 2004. 284 с.

4. Гумбольдт В. Характер языка и характер народа (отрывок). Язык и философия культуры. Москва : Прогресс, 1985. С. 370-381.

5. Караулов Ю.Н. Общая и русская идеография. Москва : Наука, 1976.

6. Колшанский Г.В. Объективная картина мира в познании и языке. Москва : Наука, 1990.

7. Кубрякова Е.С. Роль словообразования в формировании языковой картины мира. Роль человеческого фактора в языке: Язык и картина мира / Отв. ред. Б.А. Серебренников; АН СССР. Москва : Наука, 1988. С. 141-172.

8. Лисиченко Л.А. Людина і мовна картина світу. Ритми сучасної філологіі: до 50-річчя професора Т.А. Космеди. Львів : ПАІС, 2007. C. 69-74.

9. Постовалова В.И. Картина мира в жизнедеятельности человека. Роль человеческого фактора в языке: Язык и картина мира / Отв. ред. Б.А. Серебренников; АН СССР, Ин-т языкознания. Москва : Наука, 1988. С. 8-69.

10. Потебня А.А. Мысль и язык. Слово и миф. Москва : Правда, 1989. С. 17-200.

11. Соколовская Ж.П. «Картина мира» в значениях слов. «Семантические фантазии» или «катехизис семантики». Симферополь : Таврия, 1993. 232 с.

12. Тер-Минасова С.Г. Язык и межкультурная коммуникация. Москва : Slovo, 2000. 264 c.
Плотнікова Н. В. Історія становлення мовної і концептуальної картин світу

Анотація. Останніми роками зросло зацікавлення до явища взаємодії двох феноменів людської життєдіяльності - мови і культури. Саме тому проблема дослідження культурної самобутності народу, що відображається у мовній картині світу (МКС), набуває все більшої значущості. МКС тісно пов'язана із концептуальною картиною світу (ККС), оскільки остання існує у вигляді концептів, що мають мовне вираження. Статтю присвячено теоретичним засадам фундаментальних понять сучасної лінгвістики, до яких належать поняття «мовна картина світу» та «концептуальна картина світу». Традиційно науковці розподіляють картину світу на мовну картину світу - зображення довкілля, що реалізується засобами мовних номінацій, та концептуальну картину світу - систему понять, сформованих на основі уявлень людини, що складається з концептів. Нині питання про дослідження картин світу залишається відкритим, зокрема триває розробка загальних теоретичних засад: номінації та дефініції базових понять, їх структури. Питання структури розв'язується по-різному: від максимального зближення мовної і концептуальної картин до визнання різного ступеня своєрідності відображення світу в кожній мові. Погляди науковців на взаємодію цих двох картин світу можна умовно поділити на чотири групи: 1) мовна картина світу та концептуальна картина світу не розмежовуються, оскільки мовної картини світу як сукупності знань людини про світ, що функціонують у мові, не існує (Г. Колшанський); 2) мовна картина світу повністю покриває зміст концептуальної картини світу, тобто мовна картина світу робить картину світу точнішою (Г. Брутян, Ж. Соколовська); 3) мовна картина світу існує як частина концептуальної картини світу, що є багатшою, ніж мовна (Ю. Караулов, О. Кубрякова, Б. Серебренников); 4) мовна картина світу та концептуальна картина світу поєднуються, але не покривають одна одну (I. Голубовська, Т. Космеда, Л. Лисиченко, С. Тер-Мінасова). Остаточно невирішеною є також проблема класифікації та взагалі існування часткових картин, що і розглядається у представленому дослідженні.

Ключові слова: концепт, концептосфера, мікроконцептосфера, мовна картина світу, концептуальна картина світу. 